\title{
EVALUATING THE OPERATIONAL AND ENVIRONMENTAL BENEFITS OF A SMART ROUNDABOUT
}

\author{
K. Alkhaledi \\ Department of Industrial and Management Systems Engineering \\ Kuwait University, Kuwait \\ hf.s@ku.edu.kw
}

\begin{abstract}
Vehicle fuel consumption and emission rates in Kuwait have increased considerably over recent decades, and are now causing health and economic problems. A three-lane smart roundabout is a new and innovative design idea that can help to mitigate these issues. The smart roundabout was designed with a dedicated exit lane on the right side of each entryway, and a U-turn path connecting each adjacent entry and exit road. Both features permit vehicles to turn in specific directions without needing to enter the roundabout itself. Underground tunnels were designed for pedestrian and cyclist use. The objective of this study was to measure the impact of a smart roundabout on vehicle fuel consumption and on emissions of carbon dioxide, carbon monoxide, nitrogen oxides, and hydrocarbons. These results were then compared with those of a traditional roundabout and of a lightsignalised intersection. Two light-signalised intersections with different traffic volumes were chosen for this study and simulated in their present state, as replaced by traditional roundabouts; and as replaced by smart roundabouts using the SIDRA 6.0 software. The smart roundabout allowed traffic to proceed with minimal delay and idling time, significantly reducing vehicle fuel consumption and emissions in comparison with a traditional roundabout or light-signalised intersection. Furthermore, the smart roundabout allowed pedestrians and cyclists to move safely through the intersection without interacting with vehicular traffic.
\end{abstract}

\section{OPSOMMING}

Voertuig brandstofverbruik en emissietempo's in Koeweit het aansienlik verhoog oor die laaste paar dekades en veroorsaak gesondheid- en ekonomiese probleme. A drie-laan slim verkeersirkel is ' $n$ nuwe en innoverende ontwerp wat kan bydrae tot die verligting van hierdie kwessies. Die slim verkeersirkel is ontwerp met ' $n$ toegewyde uitgangslaan aan die regterkant van elke ingang en ' $\mathrm{n} U$-draai baan wat naburige ingang- en uitgangslane verbind. Beide kenmerke laat voertuie toe om in spesifieke rigtings te draai sonder om die verkeersirkel te betree. Ondergrondse tonnels is gebruik vir voetgangers en fietsryers. Die doel van die studie is om die impak van so ' $n$ slim verkeersirkel op die brandstofverbruik en uitlaat van koolstofdioksied, koolstofmonoksied, stikstofoksiede en hidrokoolstowwe te meet. Die resultate is dan met dié van ' $n$ tradisionele verkeersirkel en ' $n$ verkeersligkruising vergelyk. Twee verkeersligkruisings met verskillende verkeervolumes is gekies vir hierdie studie en in hul huidige toestand, met tradisionele verkeersirkels en met die voorgestelde slim verkeersirkel, met behulp van die SIDRA 6.0 sagteware gesimuleer. Die slim verkeersirkel het die verkeer met minimale vertraging en luier tyd laat vloei wat die brandstofverbruik en uitlaatgasse noemenswaardig laat verminder het. Verder het die slim verkeersirkel voetgangers en fietsryers met veilige deurgang deur die kruising verskaf sonder om met die padverkeer te meng. 
Roundabouts are circular intersections with specific traffic control features that include yield control of entering traffic, channelised approaches, and appropriate geometric curvature. Roundabouts were designed as one-way circulating roadways that give priority to circulating traffic over approaching traffic, which must yield. The speed on such a circular roadway is typically less than $50 \mathrm{~km} / \mathrm{h}$. Roundabouts are popular in Europe and other parts of the world, and in the past decade have been increasingly used as part of the transportation system in the United States of America (USA) [1].

Roundabouts were first introduced in Kuwait around the mid-1950s. For operational analysis and design purposes, it is useful to highlight the advantages and disadvantages of traditional roundabouts and to compare them with those of traffic light intersections. The time spent sitting at a traffic light can cause major delays in a morning or evening commute [2], while traditional roundabouts keep traffic moving more fluently than traffic-light intersections [3]. Traditional roundabouts have been improved in many ways; however, more work needs to be done to reduce vehicle-to-vehicle, vehicle-to-pedestrian, and vehicle-to-cyclist conflicts (Figure 1). A conflict point can be defined as the location where the paths between two moving entities cross, queue, diverge, or merge; conflicts can potentially cause serious accidents or traffic delays [3].

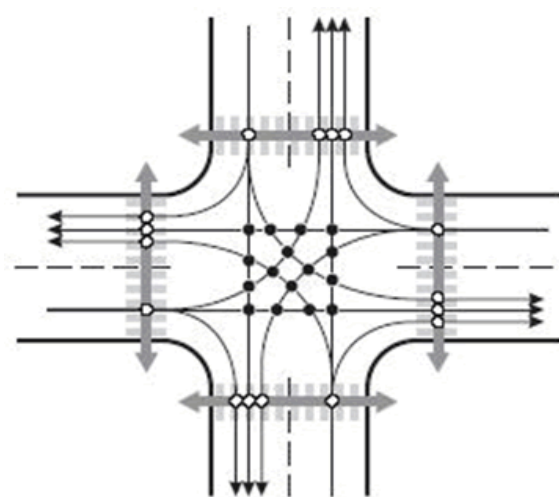

A o Vehicle to pedestrian conflicts

- Vehicle to vehicle conflicts

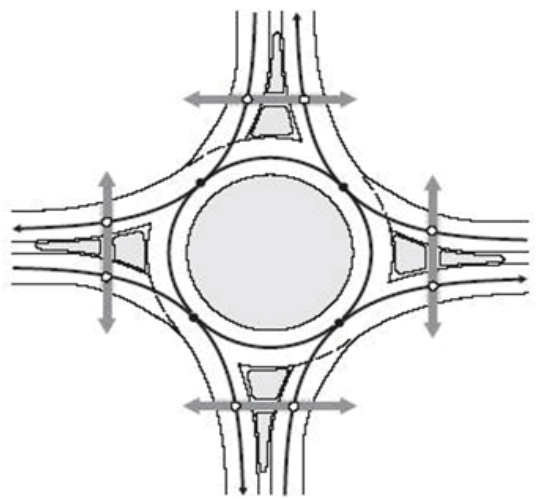

B o Vehicle to pedestrian conflicts - Vehicle to vehicle conflicts

Figure 1: Conflict points at: A) traffic light crossing zone B) traditional roundabout zone [4]

Crashes at conventional traffic light intersections can be more serious than those at roundabout intersections for two reasons. First, vehicle speeds are typically higher at traffic light intersections than they are at roundabouts. Second, pedestrians crossing at traffic lights have more places to check for vehicles than they do at roundabouts [3].

A study conducted in Virginia in the USA indicated that replacing ten traffic-light-controlled intersections with traditional roundabouts saved more than 200,000 gallons of fuel per year [5]. Another study conducted by the Washington State Department of Transportation found that one gallon of fuel was saved per 365 vehicles moving through a traditional roundabout per day, compared with the same intersection controlled by a traffic light [6].

In addition, a study was conducted in Kansas, USA to measure the environmental impact of traditional roundabouts. Six sites with different traffic volumes were chosen. Vehicle movements at the intersections were videotaped, and the traffic flow data was extracted and analysed using the SIDRA 2.0 software. Four parameters were chosen to measure the environmental impact of roundabouts. The four outputs gave the rates of emission of carbon dioxide $\left(\mathrm{CO}_{2}\right)$, carbon monoxide $(\mathrm{CO})$, hydrocarbons $(\mathrm{HC})$, and nitrous oxides $\left(\mathrm{NO}_{\mathrm{x}}\right)$ in 
$\mathrm{kg} / \mathrm{h}$. The study found that a modern roundabout performed better than did the existing intersections in reducing vehicular emissions. The study was limited by low traffic volumes, and it investigated only single- or double-lane roundabouts controlled by two-way or allway stop signs [7].

Another study in Virginia, USA evaluated the traffic performance, environmental impact, and safety of double-lane roundabouts compared with traffic-light-controlled intersections. The results showed that roundabouts improved the efficiency of traffic flow and reduced vehicle emissions and fuel consumption. Installing roundabouts in place of intersections governed by traffic lights or stop signs was found to reduce carbon monoxide emissions by 15-45 per cent, nitrous oxide emissions by 33-44 per cent, carbon dioxide emissions by 2334 per cent, and hydrocarbon emissions by $0-40$ per cent [8].

Varhelyi [9] reported that converting traffic light-signalised or stop sign intersections to traditional roundabouts decreased the carbon monoxide emissions by 32 per cent, nitrous oxide emissions by 34 per cent, carbon dioxide emissions by 37 per cent, and hydrocarbon emissions by 42 per cent.

In Sweden, researchers compared vehicle-to-pedestrian crash data from 72 roundabouts with the expected values from comparable traffic light intersections. They concluded that for single-lane roundabouts, there were three to four times fewer vehicle-to-pedestrian crashes at the roundabouts than at traffic-light-controlled intersections; for two-lane roundabouts, the crash risk was found to be similar to that of comparable intersections [10].

A safety study in the Netherlands of 181 signalised intersections converted to traditional roundabouts showed a 73 per cent decrease in average vehicle-to-pedestrian crashes [11]. In addition, a German study of 25 signalised intersections that were converted to modern roundabouts showed a 75 per cent decrease in the average number of vehicle-to-pedestrian crashes [12]. And a study conducted in Victoria, Australia on 73 roundabouts indicated that the use of roundabouts instead of traffic light or stop sign-controlled intersections reduced the casualty rate by 74 per cent [13].

The replacement of eight light-signalised intersections by roundabouts in Maryland, USA - a leading state in constructing roundabouts - resulted in a 64 per cent reduction in crashes and an 83 per cent reduction in injury crashes per year [14]. A study conducted on the safety performance of 38 roundabouts in London, England reported that the use of roundabouts reduced the accident rate by 31 per cent [15].

The results of a study by Persaud et al. showed that under many traffic conditions, traditional roundabouts can cause users fewer delays than traffic light control or all-way stop sign control intersections [16]. Recently, the number of cars on Kuwait's roads has increased dramatically. A study by the Higher Traffic Council (HTC) in Kuwait showed a six to nine per cent annual increase in the number of vehicles [17]. The World Bank reported that there are 450 passenger cars per 1,000 people in Kuwait [18].

Traditional roundabouts in Kuwait often include one or more problematic operational or design elements. Higher volumes of vehicles can reduce the fluidity and capacity of roundabouts. Traffic congestion along major roads in Kuwait causes an increase in air pollution, which has been linked to many health problems. The World Health Organisation (WHO) reported Kuwait as being one of the ten most polluted countries in the world [19].

The objective of this study was to simulate the impact of a smart roundabout on vehicle fuel consumption and emissions of carbon dioxide $\left(\mathrm{CO}_{2}\right)$, carbon monoxide $(\mathrm{CO})$, nitrogen oxides $\left(\mathrm{NO}_{\mathrm{x}}\right)$, and hydrocarbons $(\mathrm{HC})$. These results were then compared with those of a traditional roundabout and a light-signalised intersection. 
When vehicles enter a four-way roundabout, there are four ways to exit: vehicles can turn right, continue straight, turn left, or turn around. A newly-proposed smart roundabout was designed with three distinct features improving the layout of traditional roundabouts. An exit lane on the right side of each entryway allowed vehicles to turn right without entering the roundabout. A U-turn in the splitter island between each adjacent entry and exit road allowed vehicles to turn around without entering the roundabout. Underground tunnels allowed pedestrians and cyclists to travel without crossing vehicle traffic. The tunnels would eliminate all vehicle-to-pedestrian and vehicle-to-cyclist conflict points, thus reducing the number of accidents and making daily commutes easier. The tunnel entrance used a flat floor to make it easier for runners, cyclists, people with disabilities, and the elderly to use it (see Figure 2).

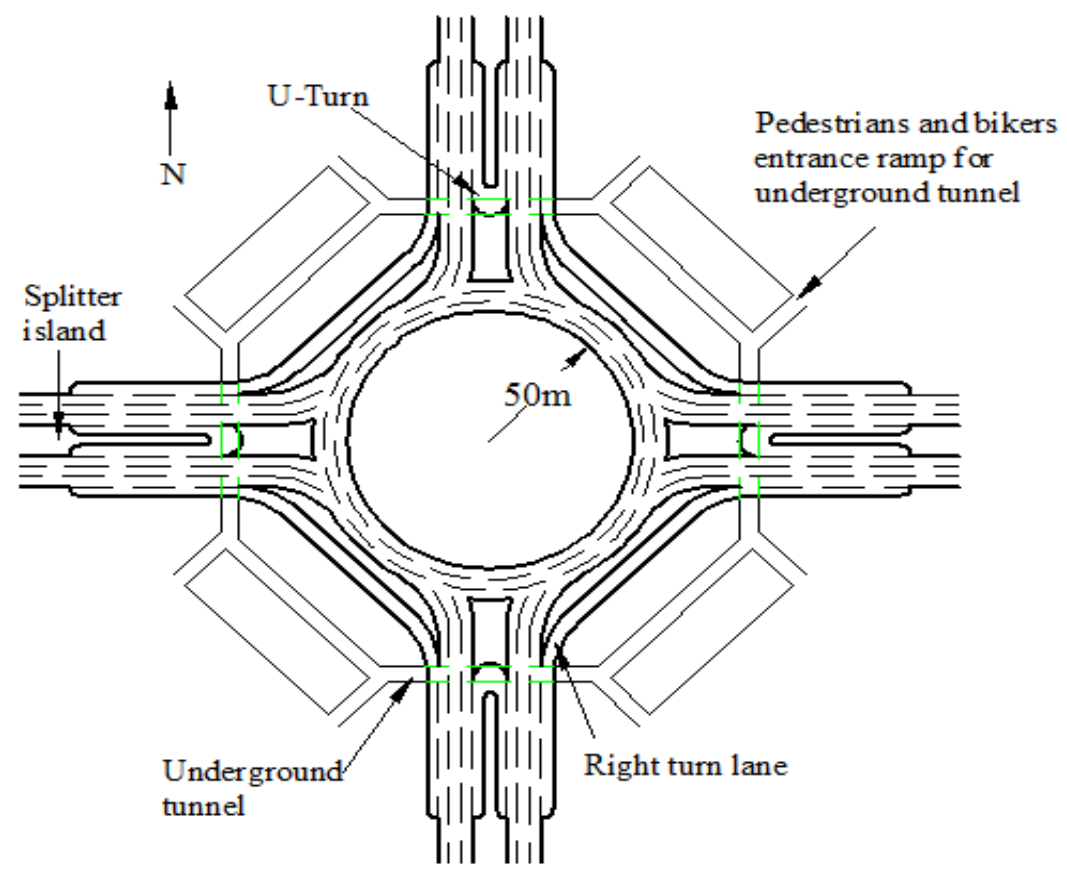

Figure 2: Improved smart roundabout layout

To examine the effective diameters and design size of the roundabout for this study, different diameters ranging from 20 to 80 metres were modelled.

Two busy intersections were selected in this study. The first site was the intersection between Ahmed Al-Jaber Street and Mubarak Al-Kabeer Street (i.e., the Dirwaza intersection) in downtown Kuwait City, Kuwait; and the second site was the intersection between Beirut Street and Tunis Street (i.e., the Beirut intersection) in Hawally, Kuwait. Both intersections have three lanes going in each direction. Ahmed Al-Jaber Street runs east-west, and Mubarak Al-Kabeer Street runs north-south. Beirut Street runs east-west, and Tunis Street runs north-south. Both test sites are controlled by traffic lights.

\subsection{Visual data collection}

The Department of Traffic has placed a monitoring camera mounted on a seven-metre-tall pole above each intersection. The cameras are connected to TV/DVR units at the Department of Traffic's control room. The camera placements were designed to provide a $360^{\circ}$ view and to record the traffic flow at the intersection. The video images were recorded and saved digitally in the control room. 
Video traffic data was collected for the morning commute (7:00 to 9:00am) and afternoon (1:30 to $3: 30 \mathrm{pm})$ peak hours during November 2013. The data was collected for one week without adverse weather conditions. All videos were studied visually to count the number of vehicles per hour (vph) crossing each intersection. Traffic counts were collected and catalogued into 15-minute periods. Results showed almost identical traffic volume for morning and afternoon peak hours. The peak hour was defined as the four consecutive 15minute periods in which the greatest number of vehicles was observed. Two averages were calculated from the morning and afternoon data sets (see Tables 1 and 2).

Table 1: Recorded average traffic volume and direction for the Dirwaza intersection

\begin{tabular}{|c|c|c|c|c|}
\hline Incoming Direction & $\begin{array}{c}\text { U-turn } \\
\text { (vph) }\end{array}$ & $\begin{array}{c}\text { Left } \\
\text { (vph) }\end{array}$ & $\begin{array}{c}\text { Straight } \\
\text { (vph) }\end{array}$ & $\begin{array}{c}\text { Right } \\
\text { (vph) }\end{array}$ \\
\hline South & 20 & 660 & 800 & 676 \\
\hline West & 76 & 244 & 752 & 740 \\
\hline North & 24 & 288 & 424 & 396 \\
\hline East & 12 & 612 & 1212 & 908 \\
\hline
\end{tabular}

Table 2: Recorded average traffic volume and direction for the Beirut intersection

\begin{tabular}{|c|c|c|c|c|}
\hline Incoming Direction & $\begin{array}{c}\text { U-turn } \\
(\mathrm{vph})\end{array}$ & $\begin{array}{c}\text { Left } \\
(\mathrm{vph})\end{array}$ & $\begin{array}{c}\text { Straight } \\
(\mathrm{vph})\end{array}$ & $\begin{array}{c}\text { Right } \\
(\mathrm{vph})\end{array}$ \\
\hline South & 356 & 872 & 3788 & 356 \\
\hline West & 72 & 520 & 104 & 352 \\
\hline North & 468 & 208 & 2060 & 600 \\
\hline East & 20 & 588 & 148 & 1300 \\
\hline
\end{tabular}

The newly-designed smart roundabout was modelled using SIDRA version 6.0 software designed specifically for analysing traffic flow at signalised intersections, non-signalised intersections, and roundabouts [20].

The software inputs included the road geometry, traffic counts, and turning movements. The SIDRA program uses a set of equations that use vehicle parameters (such as mass and fuel efficiency), road grade, and relevant speeds to calculate fuel consumption and emission rate.

A road's capacity is a measurement of traffic flow that compares the number of vehicles using the road with the number of vehicles it is designed to accommodate. For this study, 95 per cent capacity was used.

Only signalised intersections that are governed by traffic lights were considered in the simulation. Differences between three types of intersections (signalised intersections, traditional roundabouts, and smart roundabouts) were compared. The number of approach lanes for each intersection was the same.

Five factors were considered to measure the effectiveness of the smart roundabout: vehicle fuel consumption, and the emission rates for $\mathrm{CO}_{2}, \mathrm{CO}, \mathrm{NO}_{\mathrm{x}}$, and $\mathrm{HC}$.

\section{RESULTS}

Replacing the Dirwaza traffic light intersection with a smart roundabout (compared with replacing it with a traditional roundabout) was shown to reduce the number of vehicles 
entering by 35.7 per cent. Conflicts between vehicles and pedestrians and cyclists were eliminated in the new smart roundabout design.

The five factors that were considered to measure the effectiveness of the smart roundabout for the Dirwaza intersection were fuel consumption, $\mathrm{CO}_{2}, \mathrm{CO}, \mathrm{NO}_{x}$, and $\mathrm{HC}$ (Tables 3, 4, and $5)$.

Table 3: Results for the smart roundabout

\begin{tabular}{|c|c|c|c|c|c|}
\hline $\begin{array}{c}\text { Diameter } \\
(\mathrm{m})\end{array}$ & $\begin{array}{c}\text { Fuel } \\
(\mathrm{L} / \mathrm{h})\end{array}$ & $\begin{array}{c}\mathrm{CO}_{2} \\
\mathrm{~kg} / \mathrm{h}\end{array}$ & $\begin{array}{c}\mathrm{CO} \\
\mathrm{kg} / \mathrm{h}\end{array}$ & $\begin{array}{c}\mathrm{HC} \\
\mathrm{kg} / \mathrm{h}\end{array}$ & $\mathrm{NO}_{\times} \mathrm{kg} / \mathrm{h}$ \\
\hline 20 & 30.3 & 71.6 & 0.22 & 0.03 & 0.161 \\
\hline 25 & 30.2 & 71.5 & 0.22 & 0.03 & 0.16 \\
\hline 30 & 30.2 & 71.4 & 0.22 & 0.029 & 0.16 \\
\hline 35 & 30.1 & 71.2 & 0.22 & 0.029 & 0.158 \\
\hline 40 & 30 & 71 & 0.22 & 0.029 & 0.158 \\
\hline 45 & 29.9 & 70.9 & 0.22 & 0.029 & 0.157 \\
\hline 50 & 29.9 & 70.7 & 0.22 & 0.029 & 0.156 \\
\hline 55 & 30.1 & 71.2 & 0.22 & 0.029 & 0.156 \\
\hline 60 & 30.5 & 72.1 & 0.23 & 0.029 & 0.156 \\
\hline 65 & 31 & 73.3 & 0.23 & 0.03 & 0.156 \\
\hline 70 & 30.9 & 73.2 & 0.23 & 0.029 & 0.156 \\
\hline 75 & 30.9 & 73.2 & 0.23 & 0.029 & 0.156 \\
\hline 80 & 30.9 & 73.2 & 0.23 & 0.029 & 0.156 \\
\hline
\end{tabular}

Table 4: Results for the traditional roundabout

\begin{tabular}{|c|c|c|c|c|c|}
\hline $\begin{array}{c}\text { Diameter } \\
(\mathrm{m})\end{array}$ & $\begin{array}{c}\text { Fuel } \\
\mathrm{L} / \mathrm{h}\end{array}$ & $\begin{array}{c}\mathrm{CO} 2 \\
\mathrm{~kg} / \mathrm{h}\end{array}$ & $\begin{array}{c}\mathrm{Co} \\
\mathrm{kg} / \mathrm{h}\end{array}$ & $\begin{array}{c}\mathrm{HC} \\
\mathrm{kg} / \mathrm{h}\end{array}$ & $\begin{array}{c}\mathrm{NO}_{\mathrm{x}} \\
\mathrm{kg} / \mathrm{h}\end{array}$ \\
\hline 20 & 65.7 & 155.6 & 0.51 & 0.062 & 0.29 \\
\hline 25 & 65.7 & 155.5 & 0.51 & 0.062 & 0.289 \\
\hline 30 & 65.7 & 155.4 & 0.51 & 0.062 & 0.288 \\
\hline 35 & 65.6 & 155.2 & 0.51 & 0.062 & 0.287 \\
\hline 40 & 65.5 & 155.1 & 0.51 & 0.062 & 0.286 \\
\hline 45 & 65.5 & 154.9 & 0.51 & 0.061 & 0.286 \\
\hline 50 & 65.4 & 154.8 & 0.51 & 0.061 & 0.285 \\
\hline 55 & 65.6 & 155.3 & 0.51 & 0.061 & 0.285 \\
\hline 60 & 66 & 156.2 & 0.51 & 0.062 & 0.285 \\
\hline 65 & 66.5 & 157.3 & 0.52 & 0.062 & 0.285 \\
\hline 70 & 66.4 & 157.2 & 0.51 & 0.062 & 0.285 \\
\hline 75 & 66.4 & 157.2 & 0.51 & 0.062 & 0.285 \\
\hline 80 & 66.4 & 157.2 & 0.51 & 0.062 & 0.285 \\
\hline
\end{tabular}


Table 5: Results for the traffic light intersection

\begin{tabular}{|c|c|c|c|c|}
\hline $\begin{array}{l}\text { Fuel } \\
\mathrm{L} / \mathrm{h}\end{array}$ & $\begin{array}{c}\mathrm{CO}_{2} \\
\mathrm{~kg} / \mathrm{h}\end{array}$ & $\begin{array}{c}\mathrm{Co} \\
\mathrm{kg} / \mathrm{h}\end{array}$ & $\begin{array}{c}\mathrm{HC} \\
\mathrm{kg} / \mathrm{h}\end{array}$ & $\begin{array}{c}\mathrm{NO}_{\mathrm{x}} \\
\mathrm{kg} / \mathrm{h}\end{array}$ \\
\hline 77.9 & 184.3 & 0.61 & 0.108 & 0.299 \\
\hline
\end{tabular}

After varying the diameter of the newly-designed roundabout for the Dirwaza intersection from 20 to 80 metres, the optimal roundabout diameter for all five tested factors was found to be 50 metres. For that optimised data set, the five factors were compared between all three types of intersections.

There was 61.62 per cent less fuel consumed at the smart roundabout compared with the light-signalised intersection. There was 16.05 per cent less fuel consumed at the traditional roundabout compared with the light-signalised intersection. There was 54.28 per cent less fuel consumed at the smart roundabout compared with the traditional roundabout.

Furthermore, vehicles at the smart roundabout emitted 61.64 per cent less $\mathrm{CO}_{2}$ than at the light-signalised intersection. Vehicles at the traditional roundabout emitted 16.01 per cent less $\mathrm{CO}_{2}$ than at the light-signalised intersection. And at the smart roundabout, vehicles emitted 54.33 per cent less $\mathrm{CO}_{2}$ than at the traditional roundabout.

Vehicles at the smart roundabout emitted 63.93 per cent less $\mathrm{CO}$ than at the lightsignalised intersection. Vehicles at the traditional roundabout emitted 16.39 per cent less $\mathrm{CO}$ than at the light-signalised intersection. At the smart roundabout, vehicles emitted 56.86 per cent less $\mathrm{CO}$ than at the traditional roundabout.

Vehicles at the smart roundabout emitted 73.15 per cent less HC than at the lightsignalised intersection. Vehicles at the traditional roundabout emitted 43.52 per cent less $\mathrm{HC}$ than at the light-signalised intersection. At the smart roundabout, vehicles emitted 52.46 per cent less $\mathrm{HC}$ than at the traditional roundabout.

Vehicles at the smart roundabout emitted 47.83 per cent less $\mathrm{NO}_{\mathrm{x}}$ than at the lightsignalised intersection. Vehicles at the traditional roundabout emitted only 4.68 per cent less $\mathrm{NO}_{x}$ than at the light-signalised intersection. And at the smart roundabout, vehicles emitted 45.26 per cent less $\mathrm{NO}_{x}$ than at the traditional roundabout.

Replacing the Beirut traffic light intersection with a smart roundabout was shown to reduce the number of vehicles entering by 29.8 per cent, compared with replacing it with a traditional roundabout. Conflicts between vehicles and pedestrians and cyclists were eliminated in the new smart roundabout design.

The five factors that were considered to measure the effectiveness of the smartroundabout for the Beirut intersection were fuel consumption, $\mathrm{CO}_{2}, \mathrm{CO}, \mathrm{NO}_{x}$, and $\mathrm{HC}$ (Tables 6, 7, and 8).

After varying the diameter of the newly-designed roundabout for the Beirut intersection from 20 to 80 metres, the optimal roundabout diameter for all five tested factors was also found to be 50 metres. For that optimised data set, the five factors were compared between all three types of intersections.

There was 64.31 per cent less fuel consumed at the smart roundabout compared with the light-signalised intersection. There was 17.31 per cent less fuel consumed at the traditional roundabout compared with the light-signalised intersection. There was 56.84 per cent less fuel consumed at the smart roundabout compared with the traditional roundabout. 
Table 6: Results for the smart roundabout

\begin{tabular}{|c|c|c|c|c|c|}
\hline Diameter $(\mathrm{m})$ & $\begin{array}{c}\text { Fuel } \\
\mathrm{L} / \mathrm{h}\end{array}$ & $\begin{array}{c}\mathrm{CO}_{2} \\
\mathrm{Kg} / \mathrm{h}\end{array}$ & $\begin{array}{c}\mathrm{CO} \\
\mathrm{kg} / \mathrm{h}\end{array}$ & $\begin{array}{c}\mathrm{HC} \\
\mathrm{kg} / \mathrm{h}\end{array}$ & $\begin{array}{c}\mathrm{NO}_{\mathrm{x}} \\
\mathrm{kg} / \mathrm{h}\end{array}$ \\
\hline 20 & 37.8 & 89.0 & 0.31 & 0.043 & 0.120 \\
\hline 25 & 37.6 & 88.7 & 0.31 & 0.043 & 0.119 \\
\hline 30 & 37.5 & 88.3 & 0.31 & 0.042 & 0.118 \\
\hline 35 & 37.3 & 87.9 & 0.30 & 0.042 & 0.117 \\
\hline 40 & 37.2 & 87.6 & 0.30 & 0.041 & 0.116 \\
\hline 45 & 37.0 & 87.2 & 0.30 & 0.041 & 0.115 \\
\hline 50 & 36.9 & 86.9 & 0.30 & 0.040 & 0.115 \\
\hline 55 & 37.2 & 87.8 & 0.30 & 0.041 & 0.115 \\
\hline 60 & 37.9 & 89.4 & 0.31 & 0.041 & 0.115 \\
\hline 65 & 38.8 & 91.4 & 0.32 & 0.042 & 0.115 \\
\hline 70 & 38.7 & 91.1 & 0.32 & 0.042 & 0.115 \\
\hline 75 & 38.5 & 90.9 & 0.32 & 0.042 & 0.115 \\
\hline 80 & 38.5 & 90.6 & 0.32 & 0.042 & 0.115 \\
\hline & & & & & \\
\hline
\end{tabular}

Table 7: Results for the traditional roundabout

\begin{tabular}{|c|c|c|c|c|c|}
\hline Diameter $(\mathrm{m})$ & $\begin{array}{c}\text { Fuel } \\
\mathrm{L} / \mathrm{h}\end{array}$ & $\begin{array}{c}\mathrm{CO}_{2} \\
\mathrm{~kg} / \mathrm{h}\end{array}$ & $\begin{array}{c}\mathrm{CO} \\
\mathrm{kg} / \mathrm{h}\end{array}$ & $\begin{array}{c}\mathrm{HC} \\
\mathrm{kg} / \mathrm{h}\end{array}$ & $\begin{array}{c}\mathrm{NO}{ }_{\mathrm{x}} \\
\mathrm{kg} / \mathrm{h}\end{array}$ \\
\hline 20 & 86.2 & 203.3 & 0.73 & 0.092 & 0.217 \\
\hline 25 & 86.1 & 203.0 & 0.73 & 0.092 & 0.217 \\
\hline 30 & 86.0 & 202.7 & 0.73 & 0.092 & 0.216 \\
\hline 35 & 85.9 & 202.4 & 0.73 & 0.091 & 0.214 \\
\hline 40 & 85.7 & 202.1 & 0.73 & 0.091 & 0.214 \\
\hline 45 & 85.6 & 201.8 & 0.73 & 0.090 & 0.213 \\
\hline 50 & 85.5 & 201.4 & 0.72 & 0.090 & 0.213 \\
\hline 55 & 85.9 & 202.4 & 0.73 & 0.090 & 0.212 \\
\hline 60 & 86.6 & 204.0 & 0.74 & 0.091 & 0.212 \\
\hline 65 & 87.4 & 206.0 & 0.74 & 0.092 & 0.212 \\
\hline 70 & 87.3 & 205.8 & 0.74 & 0.092 & 0.212 \\
\hline 75 & 87.2 & 205.6 & 0.74 & 0.092 & 0.213 \\
\hline 80 & 87.1 & 205.4 & 0.74 & 0.091 & 0.213 \\
\hline
\end{tabular}

Table 8: Results for the traffic light intersection

\begin{tabular}{|c|c|c|c|c|}
\hline $\begin{array}{c}\text { Fuel } \\
\mathrm{L} / \mathrm{h}\end{array}$ & $\begin{array}{c}\mathrm{CO}_{2} \\
\mathrm{Kg} / \mathrm{h}\end{array}$ & $\begin{array}{c}\mathrm{CO} \\
\mathrm{kg} / \mathrm{h}\end{array}$ & $\begin{array}{c}\mathrm{HC} \\
\mathrm{kg} / \mathrm{h}\end{array}$ & $\begin{array}{c}\mathrm{NO}_{\mathrm{x}} \\
\mathrm{kg} / \mathrm{h}\end{array}$ \\
\hline 103.4 & 243.6 & 0.86 & 0.170 & 0.189 \\
\hline
\end{tabular}

Furthermore, vehicles at the smart roundabout emitted 64.33 per cent less $\mathrm{CO}_{2}$ than at the light-signalised intersection. Vehicles at the traditional roundabout emitted 17.32 per cent less $\mathrm{CO}_{2}$ than at the light-signalised intersection. At the smart roundabout, vehicles emitted 56.85 per cent less $\mathrm{CO}_{2}$ than at the traditional roundabout. 
Vehicles at the smart roundabout emitted 65.12 per cent less CO than at the lightsignalised intersection. Vehicles at the traditional roundabout emitted 16.28 per cent less $\mathrm{CO}$ than at the light-signalised intersection. At the smart roundabout, vehicles emitted 58.33 per cent less $\mathrm{CO}$ than at the traditional roundabout.

Additionally, vehicles at the smart roundabout emitted 76.47 per cent less $\mathrm{HC}$ than at the light-signalised intersection. Vehicles at the traditional roundabout emitted 55.56 per cent less $\mathrm{HC}$ than at the light-signalised intersection. At the smart roundabout, vehicles emitted 54.3 per cent less $\mathrm{HC}$ than at the traditional roundabout.

Vehicles at the smart roundabout emitted 39.15 per cent less $\mathrm{NO}_{x}$ than at the lightsignalised intersection. Vehicles at the traditional roundabout emitted 46 per cent less $\mathrm{NO}_{x}$ than at the light-signalised intersection. However, at the smart roundabout, vehicles emitted 12.7 per cent more $\mathrm{NO}_{\mathrm{x}}$ than at the traditional roundabout.

\section{DISCUSSION}

Vehicle fuel consumption at the Dirwaza and Beirut smart roundabouts was drastically improved when compared with consumption at the current light-signalised intersection; and it was also improved at traditional roundabouts compared with the current intersection (see Figure 3). Fuel consumption at the smart roundabout was 54.28 per cent and 56.84 per cent less than that of the traditional roundabout for the Dirwaza and Beirut intersections respectively.

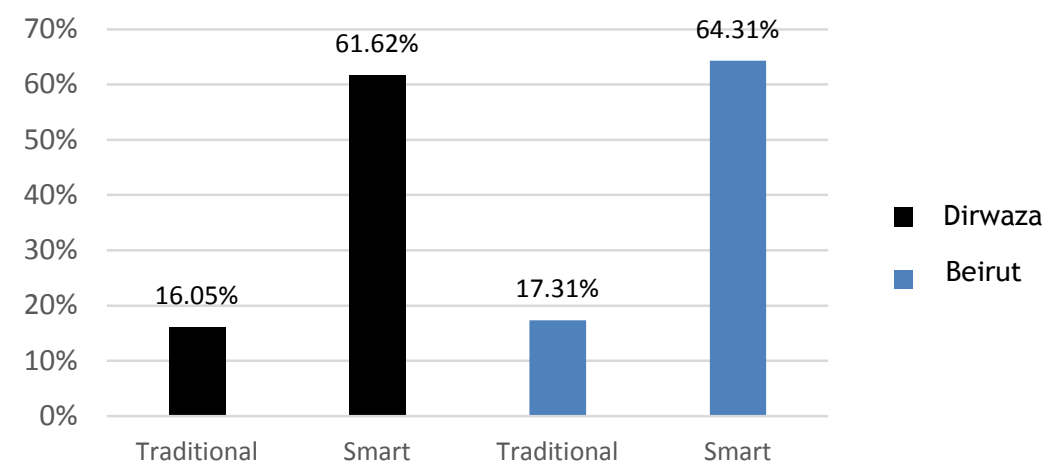

Figure 3: Smart roundabout and traditional roundabout fuel consumption reduction compared with traffic lights at Dirwaza \& Beirut intersections

Population growth in Kuwait will increase both energy use and vehicle emaission rates. In addition, the government is always trying to reduce energy use at the national level. The results of this study indicate a huge saving on fuel if smart roundabouts are used. The local government in Kuwait owns the oil sector and subsidises the fuel. Therefore, any savings on fuel consumption would save the government millions of dollars each year by spending less on fuel subsidisation. The current average price for unleaded fuel is US\$0.80 per gallon.

Traffic congestion at a traditional roundabout causes an increase in vehicular emissions, which may cause allergic reactions and pulmonary and cardiovascular diseases [21]. The increase in vehicular fuel consumption and emissions is caused by excessive idling time at busy intersections and long cycle pathways at traditional roundabouts (see Figure 4).

Vehicles at the smart roundabout not only consumed less fuel than at the traditional roundabout and the light-signalised intersection, but this also had a positive effect on the environment by decreasing vehicular emissions. The right-turn and the U-turn lanes allowed traffic to proceed with minimal delay and idling time, which resulted in reduced $\mathrm{CO}_{2}, \mathrm{CO}$, $\mathrm{HC}$, and $\mathrm{NO}_{\mathrm{x}}$ emission rates (Figure 5). 


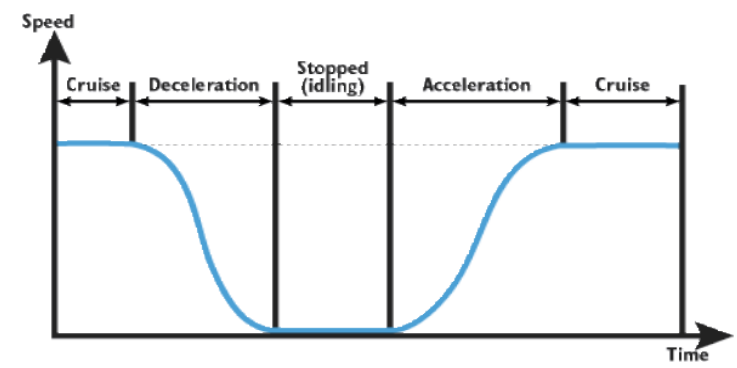

Figure 4: Graphical representation of the drive-cycle in the light-signalised intersection [20]

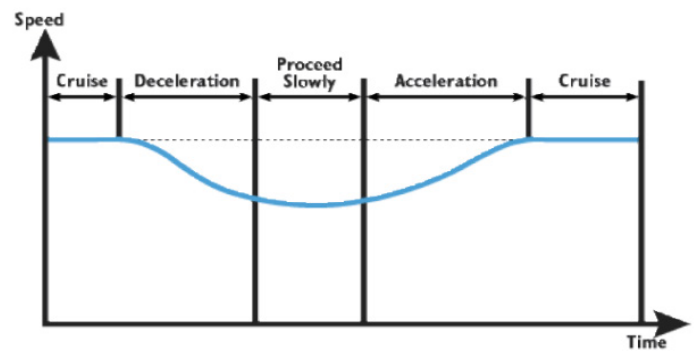

Figure 5: Graphical representation of the drive-cycle in the smart roundabout [20]

Other benefits of introducing the smart roundabout were reducing the vehicle-to-vehicle conflict points, with the underground tunnel eliminating the likelihood of vehicle-topedestrian and vehicle-to-cyclist conflicts. Furthermore, pedestrians are usually unaware of drivers' situations. Drivers may be distracted, drunk, simply not focused on the road, or in a hurry. So the crossing zone under the roundabout allowed pedestrians and cyclists to cross the intersection without interacting with vehicular traffic (see Figure 6).

Older people and people with disabilities require more time to cross the street, thereby increasing the likelihood of being hit by vehicles, resulting in more injuries or deaths, and longer traffic delays. The tunnels would help older people and people with disabilities take their time to cross the streets safely without causing any delay or interruption to the traffic flow. An elevator could also be installed at these smart roundabouts for added convenience. It may also be prudent to install lights and surveillance cameras at each tunnel to monitor any criminal or unwanted activities. A storm drain system is needed in the design to drain excess rain and ground water from tunnels.

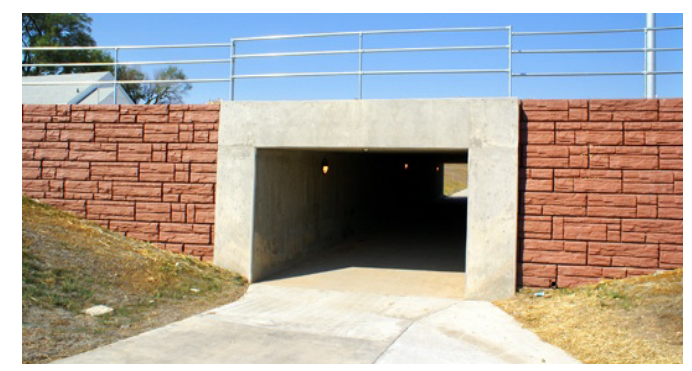

Figure 6: Underground tunnel for pedestrians and bicyclists in Lincoln, NE, USA [22]

This study did not show any attempt to calculate the actual building cost of the new smart roundabout; the actual costs would vary, and would depend on several site-specific conditions and design details such as landscaping, bulb-outs, and textured concrete. Smart roundabouts do not require signal equipment maintenance, which can cost between US\$5,000 and US\$15,000 per year [5, 23]; therefore, over the long run, smart roundabouts are typically less expensive than light-signalised intersection. 
This study found that fuel consumption and exhaust emissions were dependent on the structure of the roads. A smart-roundabout is better than a traditional roundabout or a traffic light-controlled junction, because vehicles can constantly move through them, thus eliminating waiting periods, decreasing the fuel consumption and pollution emission, and allowing pedestrians and cyclists to move safely through the intersection without interacting with vehicular traffic.

Another important benefit of the smart roundabout design is a decrease in societal costs. Reducing vehicle emissions would help to improve air quality and yield a cleaner environment, thereby reducing disease and health costs. Additionally, reduced fuel consumption decreases the fuel budget for people, companies, and the government, allowing these funds to be spent elsewhere.

Recently, due to increasingly stringent emission limits, newly-manufactured vehicles produce fewer emissions; on the other hand, the population in Kuwait is increasing, and more cars are present on the streets; so an improved street design will be required. Therefore, the smart roundabout promises to represent a substantial improvement in energy consumption and emission compared with the traditional roundabout and lightsignalised intersection. Constructing a smart roundabout is feasible, particularly at highly congested intersections.

\section{ACKNOWLEDGMENTS}

This research paper is made possible through support and funding from Kuwait University, Research Initiation Grant No. (ZE01/12).

\section{REFERENCES}

[1] Keh, A. 2010. European import has cars spinning. Heads, too. Retrieved November 2010, from: http://www.nytimes.com/2010/11/19/us/19roundabouts.html?_r=0.

[2] Coyne, A. 2011. Stuck in traffic. Retrieved December 2012, from: http://www. macleans.ca/news/canada/stuck-in-traffic/.

[3] Federal Highway Administration. 2000. Roundabouts: An informational guide. Report No. FHWARD 00-067. Retrieved February 2014, from:

http://www.fhwa. dot.gov/publications/research/safety/00067/000675.pdf.

[4] Federal Highway Administration. 2006. Pedestrian design at intersections. Retrieved October, 2012, from

http://www.fhwa.dot.gov/publications/ research/ safety/pedbike/05085/pptchapt11.cfm.

[5] Bergh, C., Retting, R.A. \& Myers, E.J. 2005. Continued reliance on traffic signals: The cost of missed opportunities to improve traffic flow and safety at urban intersections. Arlington, VA. Insurance Institute for Highway Safety.

[6] Loos, D. 2008. Hot or not: Roundabouts. The New West Magazine. Retrieved from: http://newwest.net/magazine/article/hot_or_not_roundabouts/C555/L555/.

[7] Mandavilli, S., Rys, M. \& Russell, E. 2008. Environmental impact of modern roundabouts. International Journal of Industrial Ergonomics, 38, pp. 135-142.

[8] Hu, W., McCartt, A.T., Jermakian, J.S. \& Mandavilli, S. 2013. Public opinion, traffic performance, the environment, and safety after the construction of double- lane roundabouts. Arlington, VA: Insurance Institute for Highway Safety.

[9] Varhelyi, A. 2002. The effects of small roundabouts on emissions and fuel consumption: A case study. Transportation Research Part D: Transport and Environment, 7(1), pp. 65-71.

[10] Brude, U. \& Larsson, J. 2000. What roundabout design provides the highest possible safety? Nordic Road and Transport Research, 12, pp. 17-21.

[11] Schoon, C. \& Minnen, J.V. 1994. The safety of roundabouts in the Netherlands. Traffic Engineering and Control, March, pp. 142-147.

[12] Elvik, R. 2003. Effects on road safety of converting intersections to roundabouts: Review of E evidence from non-U.S. studies. In Transportation Research Record: Journal of the Transportation Research Board, Vol. 1847, pp. 1-10.

[13] Austroads. 1993. Traffic signals. Guide to traffic engineering practice, part 7. Association of Australian State Road and Transport Authority, Sydney. 
[14] Maryland State Highway Administration. 2001. Office of Traffic and Safety, Traffic Safety Analysis Division.

[15] Alphand, F., Noelle, U. \& Guichet, B. 1991. Roundabouts and road safety: State of the art in France. In Intersections without traffic signals II, Springer-Verlag, Germany, pp. 107-125.

[16] Persaud, B.N., Retting, R.A., Garder, P.E. \& Lord, D. 2001. Crash reductions following installation of roundabouts in the United States. American Journal of Public Health, 91(4), pp. 628-631.

[17] Higher Traffic Council in Kuwait. 2003. Prospective view of traffic problems in Kuwait. Retrieved: May 2014, from: http://moi.gov.kw/portal/vEnglish/storage/ other/6\%20traffic\%20study.pdf.

[18] World Bank. 2015. International Road Federation, world road statistics and data files. Retrieved May 2014, from: http://data.worldbank.org/indicator/IS.VEH.PCAR. P3.

[19] Naidu-Ghelani, R. 2011. World's most polluted countries. Retrieved May 2013 from: http://www.cnbc.com/id/44781282/page/2.

[20] Akcelik, R. \& Besely, M. 2002. SIDRA 6.0 User Guide. Akcelik \& Associates, ARRB Transport Research Ltd, Australia.

[21] Al-Salem, S. \& Khan, A. 2010. Monitoring and modeling the trends of primary and secondary air pollution precursors: The case of the State of Kuwait. International Journal of Chemical Engineering, Vol. 2010, pp. 1-12.

[22] Olsson Associates. 2013. North $14^{\text {th }}$ Street multi-lane roundabout. Retrieved April 2013, from: http://www.olssonassociates.com/our-projects/14th-street-roundabout /index.html.

[23] Bockisch, J. 2015. Common issues when planning, designing \& constructing roundabouts. Retrieved February 2015 from: http://www.greshamsmith.com/ dialogue/january-2015/circlingyour-city-part-4. 